\title{
ANALISIS BIAYA, PENDAPATAN DAN R/C USAHA PENANGKARAN BENIH PADI VARIETAS CIHERANG \\ (Studi Kasus pada CV. Tunas Pangan Jaya di Desa Arjasari Kecamatan Leuwisari Kabupaten Tasikmalaya)
}

\author{
ANALYSIS OF COST, INCOME AND R/C CIHERANG VARIETY RICE SEED \\ BREEDING BUSINESS \\ (A Case Study on CV. Tunas Pangan Jaya in Arjasari Village Leuwisari District \\ Tasikmalaya Regency)
}

\author{
JENAL ADAM DARMAWAN ${ }^{1} *$, DINI ROCHDIANI ${ }^{2}$, SUDRADJAT $^{1}$ \\ ${ }^{1}$ Fakultas Pertanian Universitas Galuh \\ ${ }^{2}$ Fakultas Pertanian Universitas Padjajaran \\ *Email : Jadamdarmawan.94@gmail.com
}

\begin{abstract}
ABSTRAK
Penelitian ini bertujuan untuk mengetahui: 1). Besarnya biaya yang dikeluarkan CV. Tunas Pangan Jaya pada usaha Penangkaran Benih padi varietas ciherang di Desa Arjasari Kecamatan Leuwisari Kabupaten Tasikmalaya per satu kali musim tanam. 2.) Besarnya penerimaan dan pendapatan yang diperoleh CV. Tunas Pangan Jaya pada usaha Penangkaran Benih padi varietas ciherang Di desa Arjasari Kecamatan Leuwisari Kabupaten Tasikmalaya per satu kali musim tanam. 3). Besarnya R/C pada usaha Penangkaran Benih padi varietas ciherang di Desa Arjasari Kecamatan Leuwisari Kabupaten Tasikmalaya per satu kali musim tanam yang diusahakan CV. Tunas Pangan Jaya. Jenis Penelitian yang digunakan adalah metode survai, dengan kasus pada perusahaan penangkaran Benih padi varietas ciherang di CV. Tunas Pangan Jaya Desa Arjasari Kecamatan Leuwisari Kabupaten Tasikmalaya. Teknik penarikan sampel yang dilakukan yaitu secara Metode Purposive Sampling. Hasil Penelitian menunjukkan bahwa : 1). Besarnya Biaya dalam usaha penangkaran benih padi Varietas Ciherang di CV. Tunas Pangan Jaya adalah sebesar RP 225.145.934 dengan penerimaan sebesar Rp 273.680.000, sehingga diperoleh pendapatan sebesar Rp 48.534 .066 per satu kali musim tanam. 2). Besarnya R/C usaha Penangkaran benih padi varietas ciherang di CV. Tunas Pangan Jaya adalah sebesar 1,21. Artinya, bahwa setiap Rp 1 biaya yang dikeluarkan memperoleh penerimaan sebesar Rp 0,21, sehingga usaha penangkaran benih padi varietas ciherang layak untuk diusahakan.
\end{abstract}

Kata Kunci : Biaya, Penerimaan, Pendapatan, R/C.

\section{ABSTRACT}

This Study aimed to determine 1). The amount of cost CV. Tunas Pangan Jaya on company rice seed Varieties of Ciherang in Arjasari village, Leuwisari District, Tasikmalaya Regency per one planting season. 2). The Magnitude of revenue and income which is obtained CV. Tunas Pangan Jaya on company rice seed varieties of Ciherang in Arjasari village, Leuwisari District, Tasikmalaya Regency Per one planting season. 3). The Magnitude of $R / C$ ratio of Company rice seed Varieties of Ciherang in Arjasari Village, Leuwisari District, Tasikmalaya Regency Per one planting season attempted CV. Tunas Pangan Jaya.This Type of researchused in the survey method, with the case on Company breeder rice seed Varieties of Ciherang in CV. Tunas Pangan Jaya in Arjasari village, Leuwisari District, Tasikmalaya Regency. The sampling technique that was done is by Puposive Sampling. Result of study indicated that : 1) The amount of the cost in the business of ciherang varieties in CV. Tunas Pangan Jaya was $R p 225.145 .934$ with revenue of $R p 273.680 .000$ this the income obtain $R p$ 48.534 .066 per one planting season. 2)The magnitude of $R / C$ of Company rice seed varieties of ciherang in CV. Tunas Pangan Jaya in Arjasari village 1,2. That every $R p 1$ expenses incurred will receive income of $R p$ 0,21, it concluded that the cultivation of ciherang varieties was feasible.

Keyword : Cost, Revenue, Income, $R / C$. 


\section{PENDAHULUAN}

Sektor pertanian merupakan salah satu sektor yang sangat berpengaruh bagi kelangsungan hidup manusia, indonesia merupakan negara yang mayoritas masyarakatnya bermata pencaharian pada sektor pertanian (Kementan 2010). Salah satu subsektor pertanian yang menjadi prioritas untuk di kembangkan secara terus menerus adalah tanaman pangan. Padi merupakan salah satu tanaman pangan yang banyak diusahakan petani sebagai pangan nasional dan bahan pangan nasional yang telah menjadi makanan pokok sebagian besar penduduk indonesia (Budianto, 2002 dalam Jayanti,2011).

Untuk meningkatkan produksi dan produktivitas usahatani padi terus dilakukan oleh pemerintah agar keamanan pangan, pendapatan dan kesejahteraan petani terus meningkat. Salah satunya dengan pembaharuan teknologi yang bertujuan untuk memberikan kemudahan di dalam proses pertanian. Teknologi yang dimaksud adalah benih yang dapat meningkatkan hasil lebih tinggi dan bermutu baik yaitu benih bersertifikat. Penggunaan benih bersertifikat dapat menaikkan daya hasil 15\% dibandingkan dengan penggunaan benih yang tidak bersertifikat (Santoso,2005 dalam Fahmi,2008).
CV. Tunas Pangan Jaya merupakan satu-satunya perusahaan penangkar benih padi bersertifikat yang berada di Desa Arjasari Kecamatan Leuwisari Kabupaten Tasikmalaya. CV. Tunas Pangan Jaya berdiri sudah lama sekitar 10 tahun dengan memproduksi berbagai varietas padi diantaranya yang paling banyak diproduksi adalah benih padi varietas ciherang, untuk pendistribusiannya CV. Tunas Pangan Jaya memasarkannya khusus untuk daerah Tasikmalaya.

Penelitian ini bertujuan untuk mengetahui : (1). Besarnya biaya yang dikeluarkan CV. Tunas Pangan Jaya pada usaha penangkaran benih padi varietas ciherang per satu kali musim tanam, (2). Besarnya penerimaan dan pendapatan yang diperoleh CV. Tunas Pangan Jaya pada usaha penangkaran benih padi varietas ciherang per satu kali musim tanam. (3). Besarnya R/C pada usaha penangkaran benih padi varietas ciherang per satu kali musim tanam yang diusahakan CV. Tunas Pangan Jaya.

\section{METODE PENELITIAN}

Jenis penelitian yang digunakan dalam penelitian ini adalah metode studi kasus dengan mengambil kasus pada $\mathrm{CV}$. Tunas Pangan Jaya di Desa Arjasari 
Kecamatan Leuwisari Kabupaten Tasikmalaya.

Menurut Daniel (2002), metode studi kasus mirip dengan metode survai. Bedanya dalam studi kasus, populasi yang diteliti lebih terarah atau terfokus pada suatu sifat tertentu yang tidak berlaku umum. Biasanya dibatasi oleh kasus, tempat, serta waktu tertentu.

Teknik penarikan sampel dilakukan dengan metode purposive sampling yaitu pada seorang pengusaha benih padi $\mathrm{CV}$. Tunas Pangan Jaya di Desa Arjasari, dengan pertimbangan perusahaan benih padi tersebut satu satunya perusahaan benih padi di Desa Arjasari dengan produksi 50 ton benih dalam satu kali proses produksi. Menurut Hasan (2009) Purposive sampling adalah teknik penentuan sampel dengan pertimbangan tertentu. Teknik purposive sampling ini lebih cocok digunakan untuk penelitian kualitatif, atau penelitan-penelitian yang tidak memerlukan generalisasi.

Data yang diperoleh dianalisis dengan menggunakan metode deksriptif kuantitatif. Untuk menentukan biaya produksi, penerimaan, pendapatan, dan $\mathrm{R} / \mathrm{C}$ dianalisis menggunakan rumus sebagai berikut:

1. Analisis Biaya
Menurut Rodjak (2006), untuk menghitung besarnya biaya total diperoleh dengan cara menjumlahkan biaya tetap dengan biaya variabel, dan dihitung dengan rumus :

$$
\mathrm{TC}=\mathrm{FC}+\mathrm{VC}
$$

Dimana :

$\mathrm{TF}=$ Total Cost

$\mathrm{FC}=$ Fixed Cost

$\mathrm{VC}=$ Variable Cost

2. Analisis penerimaan

Menurut Suratiyah (2015), secara umum perhitungan penerimaan total adalah perkalian antara jumlah produksi (Y) dengan harga jual (Hy) dan dihitung dengan rumus sebagai berikut :

$$
\mathrm{TR}=\mathrm{Y} . \mathrm{Py}
$$

Dimana :

$\mathrm{TR}=$ Total Revenue

$\mathrm{Y}=$ Produksi yang diperoleh

Py $=$ Harga

3. Analisis pendapatan

Menurut Suratiyah

(2015), pendapatan adalah selisih antara penerimaan (TR) dan biaya total (TC) dan dihitung dengan rumus :

$$
\mathrm{Pd}=\mathrm{TR}-\mathrm{TC}
$$

Dimana :

Pd : Pendapatan

TR : Total Revenue

TC : Total Cost

4. $\mathrm{R} / \mathrm{C}$ 
Menurut Rodjak (2006), R/C adalah perbandingan antara penerimaan dengan biaya, dan dihitung dengan rumus :

$$
\mathrm{R} / \mathrm{C}=\frac{T R}{T C}
$$

Dimana :

\section{TR : Total Revenue}

\section{TC : Total Cost}

Dengan kriteria :

- $\quad \mathrm{R} / \mathrm{C}<1$, maka usaha tersebut rugi sehingga tidak layak diteruskan.

- $\quad \mathrm{R} / \mathrm{C}=1$, maka usaha tersebut tidak untung tidak rugi (impas) sehingga tidak layak diteruskan.

- R/C >1, maka usaha tersebut untung sehingga layak diteruskan.

\section{HASIL DAN PEMBAHASAN}

Proses Produksi Benih Padi Varietas Ciherang di CV. Tunas Pangan Jaya Desa Arjasari

\section{1) Penjemuran}

Penurunan kadar air perlu dilakukan dengan cara penjemuran, karena pada umumnya calon benih masih mempunyai kadar air yang tinggi. Penjemuran biasanya dilakukan di atas alas terpal hamparan, setelah itu lakukan pembalikan benih secara berkala dan hati hati. Pengeringan/ penjemuran dengan sinar matahari umumnya dilakukan selama 4-5 jam hingga mencapai kadar air yang memenuhi standar mutu benih bersertifikat (13\% atau lebih rendah).

\section{2) Pembersihan}

Pembersihan calon benih bertujuan untuk memisahkan benih dari kotoran (tanah, jerami, dan daun padi yang terbawa) juga untuk membuang benih hampa.Pembersihan dalam skala kecil dapat menggunakan tampi atau nyiru sedangkan untuk skala besar dapat menggunakan air screen cleaner.

\section{3) Packing}

Packing/Pengemasan sementara selama pengolahan benih berlangsung setelah selesai pengolahan sampai menunggu hasil uji lab keluar dan label selesai dicetak, benih dapat dikemas dalam karung plastik yang dilapis dengan kantong plastik di bagian dalamnya. Sedangkan untuk tujuan komersial/ pemasaran benih, benih sebaiknya dikemas dengan menggunakan kantong plastik ukuran 0,08 $\mathrm{mm}$ atau lebih dan di sealed rapat. Pengemasan dilakukan setelah uji lab terhadap contoh benih dinyatakan lulus oleh BPSB dan label selesai di cetak. Label benih dimasukan ke dalam kemasan sebelum di sealed, kemasan harus sesuai dengan format standar Badan Litbang Pertanian. 
4) Pemasaran

Pemasaran dilakukan oleh CV. Tunas Pangan Jaya setelah selesai proses pengemasan. Pemasaran biasanya langsung ke toko-toko pertanian yang sudah bermitra/bekerja sama ataupun ke petani yang membutuhkan. CV. Tunas Pangan Jaya memasarkan benih padi varietas ciherang dengan bentuk pack, untuk berat isi per pack nya 5 kilogram dengan harga 55.000 .

\section{Analisis Biaya}

Biaya dalam kegiatan usaha benih padi varietas ciherang merupakan biaya yang dikeluarkan selama proses produksi, antara lain biaya tetap dan biaya variabel. Biaya tetap dalam usaha Benih padi meliputi : penyusutan Bangunan produksi dan gudang sebesar Rp 1.400.000, lapangan untuk menjemur gabah sebesar Rp 625.000, air screen cleaner sebesar Rp 1.600.000, timbangan gantung sebesar $\mathrm{Rp}$ 250.000, timbangan duduk sebesar $\mathrm{Rp}$ 840.000, artco sebesar Rp 275.000, terpal sebesar Rp 300.000, mesin press sebesar Rp 800.000, sekop sebesar Rp 41.667, mobil pick up sebesar Rp 4.800.000, mesin jahit karung sebesar Rp 183.750, tenaga kerja tetap sebesar Rp 35.400.000, pajak bumi bangunan sebesar Rp 160.000, bunga modal sebesar $\mathrm{Rp} 2.800 .525$, total biaya tetap 49.475.942 .
Biaya variabel dalam usaha benih padi meliputi : Gabah sebesar Rp 155.500.000, Uji laboratorium sebesar Rp 217.700, Sablon sebesar Rp 311.000, Plastik sebesar Rp 4.354.000, Karung sebesar Rp 1.137.500, Benang jahit sebesar Rp 168.000, Bahan bakar 245.000, Transfortasi sebesar Rp 1.250.000, Tenaga kerja sebesar Rp 1.520.000, Uji lapangan sebesar Rp 1.000.000, Bunga modal sebesar Rp. 9.966.792, Total biaya variabel sebesar Rp 175.669.992.

\section{Analisis Penerimaan dan Pendapatan}

Untuk memperoleh penerimaan usaha penangkaran benih padi varietas ciherang dihitung dengan cara mengalikan hasil produksi benih padi dalam satu kali proses produksi dengan harga jual pada saat penelitian. Produksi gabah calon benih padi setelah diproses menjadi benih padi yaitu $24.880 \mathrm{~kg}$ atau $24,88 \mathrm{ton}$, hal ini berarti gabah mengalami penyusutan sekitar 20 persen dari gabah calon benih padi yang awal di beli dari petani yaitu $31.100 \mathrm{~kg}$ atau 31,1 ton. Kemudian untuk harga jual benih varietas ciherang perusahaan CV. Tunas Pangan Jaya menetapkan harga Rp 11.000/kg, namun dalam pemasarannya perusahaan tidak memproduksi dalam kemasan $1 \mathrm{~kg}$ melainkan diproduksi dalam kemasan plastik $5 \mathrm{~kg}$ sehingga harga jual per 
kemasan Rp 55.000. Dengan demikian penerimaan yang diperoleh perusahaan CV. Tunas Pangan Jaya sebesar Rp 273.680.000 per satu kali musim tanam.

Untuk mengetahui besarnya pendapatan atau keuntungan usaha penangkaran benih padi varietas ciherang dihitung dengan cara penerimaan dikurangi dengan jumlah total biaya produksi. penerimaan yang diperoleh perusahaan CV. Tunas Pangan Jaya sebesar Rp 273.680.000 dan total biaya produksi yang dikeluarkan untuk usaha penangkaran benih padi varietas ciherang sebesar $\mathrm{Rp}$ 225.145.934 . Sehingga pendapatan yang diperoleh perusahaan CV. Tunas Pangan Jaya sebesar Rp 48.534.066 per musim tanam.

\section{Analisis R/C}

Dalam kegiatan usahatani perlu adanya analisis kelayakan usaha. Hal ini berfungsi untuk mengetahui kelayakan dari usaha yang telah atau akan dijalani. Kelayakan usaha dapat diketahui dengan R/C. Suratiyah (2015) menyatakan bahwa semakin tinggi rasio penerimaan yang diterima petani maka usahatani tersebut semakin menguntungkan dan layak untuk diusahakan.

$\mathrm{R} / \mathrm{C}$ usaha penangkaran benih padi varietas ciherang pada CV. Tunas Pangan Jaya adalah sebagai berikut:

$$
\begin{aligned}
& \mathrm{R} / \mathrm{C}=\frac{\text { Penerimaan }}{\text { Total Biaya }} \\
& \mathrm{R} / \mathrm{C}=\frac{273.680 .000}{225.145 .934} \\
& \mathrm{R} / \mathrm{C}=1,21
\end{aligned}
$$

Dari perhitungan diatas dapat diketahui bahwa usaha penangkaran benih padi varietas ciherang per satu kali musim tanam memberikan nilai rasio sebesar 1,21. Hal ini menunjukkan bahwa setiap penerimaan $\mathrm{Rp}$ 1,21 akan diperoleh penerimaan sebesar 0,21. Dengan demikian usahatani benih padi varietas ciherang layak untuk diusahakan karena R/C nya lebih dari 1.

\section{KESIMPULAN DAN SARAN}

\section{Kesimpulan}

Berdasarkan hasil penelitian dan pembahasan yang telah diuraikan sebelumnya, maka dapat di simpulkan :

1. Besarnya Biaya dalam usaha penangkaran benih padi varietas ciherang di CV. Tunas Pangan Jaya adalah Rp 225.145.934 dengan penerimaan sebesar Rp 273.680.000, sehingga diperoleh pendapatan sebesar Rp 48.534.066 per satu kali musim tanam.

2. Besarnya $\mathrm{R} / \mathrm{C}$ usaha penangkaran benih padi varietas ciherang di CV. Tunas Pangan Jaya adalah 1.21 per satu kali musim tanam. Artinya, 
bahwa setiap $\mathrm{Rp} 1$ biaya yang dikeluarkan perusahaan akan memperoleh penerimaan sebesar $\mathrm{Rp}$ 0,21, sehingga layak untuk diusahakan.

\section{Saran}

1. Perusahaan mampu mempertahankan bahkan mengembangkan usahatani dengan meningkatkan kualitas dan kuantitasnya. Peningkatan kualitas benih dapat dilakukan dengan mengikuti pelatihan maupun kegiatan yang diselenggarakan oleh pemerintah khususnya dalam bidang pertanian. Peningkatan kuantitas benih dapat dilakukan salah satunya dengan memperluas lahan usahatani, selain mampu meningkatkan kuantitas, dengan perluasan lahan mampu meningkatkan pendapatan yang akan diperoleh perusahaan.

2. Perusahaan perlu melakukan penanganan lebih lanjut untuk padi yang tidak digunakan sebagai benih. Seperti dengan menggiling padi menjadi beras yang nantinya dapat di jual. Dengan demikian, dapat diperoleh pendapatan tambahan dari hasil usahatani benih padi varietas ciherang.

\section{DAFTAR PUSTAKA}

Daniel. M. 2002. Metode Penelitian Sosial Ekonomi. Bumi Aksara. Jakarta.

Fahmi, D. 2008. Analisis Sikap dan Kepuasan Petani Padi Varietas Unggul. Sosiohumaniora, Volume 18 No. 3 November 2016: 240-247.

Hasan, I. 2009. Pokok- Pokok Materi Statistik 1 (Statistik Deskriptif). PT. Bumi Aksara. Jakarta.

Jayanti, M. 2011. Faktor Faktor Yang Mempengaruhi Keputusan Petani Padi Sawah Menggunakan Benih Menurut Sumber Benih. Sosiohumaniora, Volume 18 No. 3 November 2016. 240-247.

Kementrian Pertanian. 2010. Road Map, Strategi Sektor Pertanian Menghadapi Perubahan Iklim. Kementrian Pertanian, Jakarta.

Rodjak, A. 2006. Manajemen Usahatani. Giratuna. Bandung.

Suratiyah, K. 2015. Ilmu Usahatani. Penebar Swadaya. Jakarta. 